\title{
Tata laksana Infeksi Sitomegalovirus pada Pasien Transplantasi Organ Padat
}

\author{
Lucyana, Mulya Rahma Karyanti, Nina Dwi Putri \\ Departemen Ilmu Kesehatan Anak Fakultas Kedokteran Universitas Indonesia RS Dr Cipto Mangunkusumo
}

\begin{abstract}
Abstrak. Pasien kandidat transplan organ padat merupakan populasi yang berisiko tinggi mengalami infeksi, terutama setelah transplantasi, karena pasien akan menerima terapi imunosupresan sehingga infeksi maupun reaktivasi patogen lebih mudah terjadi. Patogen penyebab morbiditas tersering adalah sitomegalovirus (CMV). Infeksi sitomegalovirus dapat bersifat simtomatik maupun asimtomatik. Penyakit CMV timbul apabila infeksi bersifat simtomatik dan dapat terjadi baik oleh infeksi primer, reaktivasi, maupun superinfeksi virus. Gejala penyakit CMV pada pasien imunokompromais dapat menjadi diseminata. Baku emas untuk mendiagnosis CMV adalah dengan polymerase chain reaction (PCR) CMV. Namun demikian, belum ada panduan tatalaksana profilaksis maupun batasan titer CMV yang memerlukan terapi. Makalah ini bertujuan untuk menelaah literatur sehingga dapat menghasilkan panduan profilaksis dan terapi penyakit CMV pada pasien transplantasi organ padat di Indonesia. Sari Pediatri 2017;19(3):172-82
\end{abstract}

Kata kunci: sitomegalovirus, transplantasi organ padat, terapi

\section{Management of Cytomegalovirus Infections in Solid Transplant Patients}

Lucyana, Mulya Rahma Karyanti, Nina Dwi Putri

\begin{abstract}
Solid organ transplant patients are constantly in high risk of infection, especially after transplantion, as they need to consume immunosuppressants medications. Infection as well as pathogen reactivation can easily occur, and among them cytomegalovirus (CMV) infection is the most prevalent. CMV infection can be symptomatic and asymptomatic. CMV disease happens when CMV infection becomes symptomatic, and CMV can be acquired form primary infection, reactivation, and superinfection. CMV disease symptoms in immunocompromised patients may have disseminated characteristics. Polymerase chain reaction (PCR) CMV is still the gold standard for diagnosis, yet guidelines for managing CMV infection/disease in solid organ transplant candidates has yet been proposed, either for prophylaxis or treatment. This article addresses those topics and practical ways to manage CMV infection in solid organ transplant patients in Indonesia. Sari Pediatri 2017;19(3):172-82
\end{abstract}

Keyword: cytomegalovirus, organ transplant patients, treatment

Alamat korespondensi: Dr. Lucyana, Departemen Ilmu Kesehatan Anak Fakultas Kedokteran Universitas Indonesia, Jl. Diponegoro no. 71 , Salemba, Jakarta Pusat. Email: Lucyana.alimsantoso@gmail.com 
Lucyana dkk: Tata laksana infeksi sitomegalovirus pada pasien transplantasi organ padat

$\mathrm{P}$ asien transplantasi organ padat merupakan populasi berisiko tinggi mengalami infeksi. Penyebab morbiditas dan mortalitas tertinggi pasien transplantasi hati di Rumah Sakit Cipto Mangunkusumo adalah infeksi. Infeksi virus merupakan salah satu etiologi yang cukup sering menyebabkan morbiditas dan mortalitas pascatransplantasi organ padat. Secara umum, jenis virus penyebab hampir sama pada seluruh resipien. Namun demikian, frekuensi, jenis infeksi, dan derajat keparahan berbeda dari segi organ yang ditransplantasikan dan status serologis resipien dan donor pra-transplantasi. ${ }^{1}$

Sitomegalovirus adalah salah satu virus patogen terpenting pada resipien transplan organ. Infeksi CMV dapat bersifat asimtomatik atau simtomatik. ${ }^{2}$ Definisi infeksi CMV adalah bukti adanya replikasi CMV, tanpa gejala, sedangkan penyakit CMV adalah infeksi CMV disertai gejala (misalnya sindrom virus berupa demam, malaise, leuko/trombositopenia, penyakit invasif jaringan). Infeksi CMV dapat berupa infeksi primer, reaktivasi dan superinfeksi.

\section{Patogenesis}

Pada infeksi primer, infeksi terjadi pada resipien yang awalnya seronegatif CMV mendapat donor yang seropositif CMV (donor +/resipien -). Sembilanpuluh persen resipien ini mengalami penyakit CMV. Pada kasus reaktivasi/superinfeksi, sekitar $15 \%$ resipien akan mengalami penyakit. Superinfeksi adalah kondisi kombinasi donor + / resipien +. Pada superinfeksi, jika donor mengalami reaktivasi maka penyakit CMV dijumpai pada 25\% resipien. ${ }^{3}$ Superinfeksi merupakan kondisi resipien seropositif CMV yang mendapat CMV eksogen dari donor CMV seropositif, selain mengalami reaktivasi dari CMV endogen. ${ }^{4}$ Infeksi CMV primer yang berasal dari organ donor terinfeksi (atau leukosit donor yang ditransmisikan pada transplantasi) memiliki angka morbiditas dan mortalitas tertinggi. ${ }^{5}$ Resipien seronegatif yang menerima organ dari donor yang seropositif memiliki risiko tertinggi. Pasien yang diterapi dengan agen imunosupresif dosis tinggi, terutama produk antilimfosit, memiliki angka tertinggi infeksi CMV tanpa memandang status imunitas sebelumnya. ${ }^{6,7}$ Namun demikian, replikasi virus pada individu yang telah memiliki kekebalan sebelumnya terhadap CMV lebih dapat dikontrol dibandingkan individu tanpa kekebalan terhadap $\mathrm{CMV}^{8}{ }^{8}$ Reaktivasi CMV atau superinfeksi dari galur CMV berbeda memiliki manifestasi yang lebih ringan, dan terjadi apabila imunitas spesifik CMV terganggu oleh obat imunosupresi, terutama yang menyebabkan deplesi limfosit T (Gambar 1).,5,

Penyakit CMV simtomatik biasanya bermanifestasi dalam 1-3 bulan pasca-transplantasi, tetapi onset dapat muncul belakangan apabila digunakan kemoprofilaksis. ${ }^{10}$ Penyakit CMV lambat didefinisikan apabila timbul penyakit dalam 3-6 bulan pasca-transplan. Hal ini berhubungan dengan lama profilaksis, yaitu 3-6 bulan. Gejala penyakit CMV berupa demam dan abnormalitas hematologis (termasuk leukopenia, limfosit atipik, dan trombositopenia) merupakan manifestasi yang sering dijumpai. Gejala CMV diseminata dapat mengenai organ viseral seperti saluran gastrointestinal, hati, dan paru. ${ }^{2,6}$

Sitomegalovirus didapat dari pajanan terhadap liur, air mata, urin, feses, air susu, semen dan sekret tubuh lain dari individu terinfeksi (Tabel 2). ${ }^{11}$ Infeksi primer CMV pada individu imunokompeten biasanya tidak bergejala atau hanya ditandai dengan demam self-limited yang disertai limfadenopati umum sehingga gejalanya mirip dengan mononukleosis infeksiosa.

Infeksi primer CMV merangsang timbulnya imunitas humoral dan selular. ${ }^{12}$ Imunoglobulin M anti CMV disekresi saat awal infeksi CMV sehingga merupakan tanda infeksi baru/akut/aktif. Beberapa minggu kemudian, IgG CMV mulai diproduksi dan dapat ditemukan sepanjang hidup. Kontrol infeksi CMV memerlukan peran CD4 dan CD8 spesifik sehingga supresi jumlah dan fungsi kedua sel tersebut dapat mengakibatkan reaktivasi CMV. ${ }^{12}$

Infeksi primer CMV menghasilkan infeksi laten CMV. Virus CMV dapat tersimpan dalam bentuk laten di berbagai sel tubuh, di antaranya makrofag, sel mononuklear, neutrofil, sel polimorfonuklear, epitel, endotel, fibroblast, sel neuron, dan sel parenkim. ${ }^{14}$ Sebaran jaringan sel tersebut dapat ditemukan di sumsum tulang, ginjal, hati, saluran cerna, paru, dan otak. Sel yang mengalami infeksi laten CMV merupakan sumber reaktivasi virus. ${ }^{4}$ Reaktivasi ini dapat terjadi secara intermiten sepanjang hidup. Pada individu imunokompeten, 
Lucyana dkk: Tata laksana infeksi sitomegalovirus pada pasien transplantasi organ padat

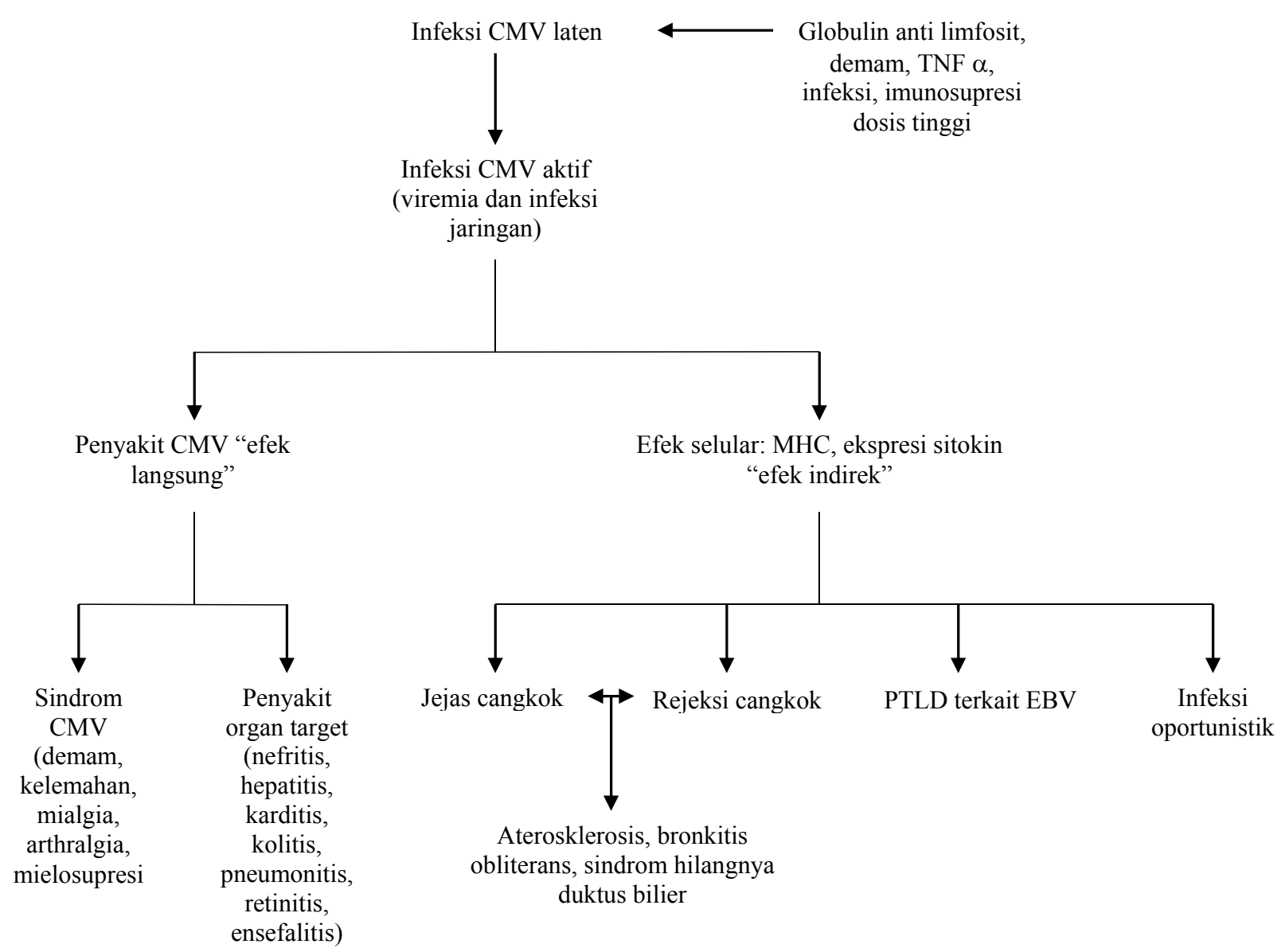

Gambar 1. Bagan infeksi CMV pada pasien transplantasi hati ${ }^{6}$

Keterangan:

CMV: cytomegalovirus; MHC: major histocompatibility complex; PTLD: posttransplan lymphoproliferative disease; EBV: EpsteinBarr virus

Sumber: Fishman JA. Infection in solid-organ transplant recipients. N Engl J Med. 2007;357:2601-14

reaktivasi ini dapat memicu memori imun yang secara efektif dapat mengontrol replikasi virus sehingga tidak menimbulkan gejala klinis. ${ }^{15}$ Pada kondisi imunitas yang rendah, seperti pasien transplan, kondisi dapat menyebabkan penyakit CMV berat karena ketidakmampuan sistem imun untuk mengontrol replikasi virus sehingga terjadi manifestasi sistemik dan penyakit invasif jaringan. ${ }^{4}$ Titer virus pada pasien dengan $\mathrm{D}+/ \mathrm{R}$ - lebih tinggi dibandingkan resipien transplan $\mathrm{R}_{+}$, demikian juga dengan insiden penyakit CMV invasif jaringan, terutama apabila resipien tidak mendapatkan terapi profilaksis CMV. Penyakit CMV biasanya muncul setelah profilaksis antiviral selesai diberikan (penyakit CMV awitan lambat). ${ }^{6}$

\section{Diagnosis}

Diagnosis penyakit CMV ditegakkan jika dijumpai gejala klinis dan penunjang berupa pemeriksaan asam nukleat kuantitatif (viral load) atau pp65 antigenemia CMV, histopatologi, atau kultur. ${ }^{16}$ Namun demikian, hasil kultur urin, atau sekret 
organ respirasi (termasuk spesimen bilas alveolar) sulit diinterpretasi karena pada pasien asimtomatik dapat positif. ${ }^{6}$ Pemeriksaan histologi dari organ yang terinfeksi masih merupakan baku emas untuk kecurigaan penyakit CMV invasif. Beberapa pemeriksaan yang dapat digunakan untuk mendeteksi kuman CMV di darah dan jaringan beserta keunggulan dan kelemahan dari masing-masing metode tertera pada Tabel 1. Perlu diperhatikan beberapa kondisi tertentu, pada pemeriksaan yang tidak seharusnya dikerjakan, misalnya pemeriksaan
CMV pp65 antigenemia kurang memiliki nilai diagnostik pada pasien leukopenia. ${ }^{13}$

\section{Pemeriksaan berbasis asam nukleat pada pasien transplantasi organ}

Nucleic acid amplification tests (NAT) merupakan metode yang dianjurkan untuk diagnosis cepat CMV pasca transplan. ${ }^{4}$ Metode ini merupakan metode paling sensitif untuk mendiagnosis CMV,

Tabel 1. Beberapa jenis pemeriksaan yang dapat digunakan untuk deteksi CMV ${ }^{13}$

\begin{tabular}{|c|c|c|c|c|c|c|}
\hline Metode & Prinsip & Jenis sampel & $\begin{array}{l}\text { Lama } \\
\text { pemeriksaan }\end{array}$ & $\begin{array}{l}\text { Hasil dan } \\
\text { kegunaan klinis }\end{array}$ & Keunggulan & Kekurangan \\
\hline \multicolumn{7}{|c|}{ Metode berbasis non asam nukleat } \\
\hline Serologi & $\begin{array}{l}\text { Deteksi } \\
\text { antibodi CMV } \\
(\mathrm{IgG}, \mathrm{IgM})\end{array}$ & Serum & 6 jam & $\begin{array}{l}\text { IgG menandakan } \\
\text { infeksi lampau } \\
\text { (laten); IgM } \\
\text { menandakan } \\
\text { infeksi akut }\end{array}$ & $\begin{array}{l}\text { Prognostik dan } \\
\text { penilaian risiko } \\
\text { donor-resipien }\end{array}$ & $\begin{array}{l}\text { Tidak dapat } \\
\text { mendiagnosis } \\
\text { CMV pada } \\
\text { resipien; } \\
\text { tidak dapat } \\
\text { menentukan } \\
\text { durasi terapi }\end{array}$ \\
\hline Histopatologi & $\begin{array}{l}\text { Infeksi CMV } \\
\text { di sel/jaringan } \\
\text { (gambaran } \\
\text { pembesaran sel } \\
\text { dengan badan } \\
\text { inklusi) }\end{array}$ & $\begin{array}{l}\text { Jaringan } \\
\text { mikroskopik }\end{array}$ & $24-48$ jam & $\begin{array}{l}\text { Deteksi sel yang } \\
\text { terinfeksi CMV } \\
\text { mengindikasikan } \\
\text { penyakit invasif } \\
\text { jaringan aktif }\end{array}$ & $\begin{array}{l}\text { Pemeriksaan } \\
\text { konfirmasi untuk } \\
\text { penyakit CMV } \\
\text { invasif jaringan; } \\
\text { sangat spesifik }\end{array}$ & $\begin{array}{l}\text { Invasive, dan } \\
\text { tidak digunakan } \\
\text { untuk monitor } \\
\text { terapi maupun } \\
\text { risiko relaps }\end{array}$ \\
\hline $\begin{array}{l}\text { Kultur virus } \\
\text { Tube culture }\end{array}$ & $\begin{array}{l}\text { Pertumbuhan } \\
\text { virus di sel } \\
\text { fibroblast } \\
\text { manusia }\end{array}$ & $\begin{array}{l}\text { Kultur sel; } \\
\text { mikroskop } \\
\text { cahaya }\end{array}$ & 2-4 minggu & $\begin{array}{l}\text { Deteksi cytopathic } \\
\text { effects (CPE) } \\
\text { karakteristik } \\
\text { menandakan } \\
\text { keberadaan virus }\end{array}$ & $\begin{array}{l}\text { Sangat spesifik untuk } \\
\text { infeksi CMV; lebih } \\
\text { sensitif dan cepat } \\
\text { daripada kultur } \\
\text { konvensional }\end{array}$ & $\begin{array}{l}\text { Lebih tidak } \\
\text { sensitif } \\
\text { dibandingkan } \\
\text { metode molekular }\end{array}$ \\
\hline Shell vial assay & $\begin{array}{l}\text { Pertumbuhan } \\
\text { virus dengan } \\
\text { deteksi } \\
\text { menggunakan } \\
\text { antibodi } \\
\text { monoklonal } \\
\text { terhadap } \\
\text { antigen virus }\end{array}$ & $\begin{array}{l}\text { Kultur sel; } \\
\text { deteksi } \\
\text { imunofloresen }\end{array}$ & $16-48$ jam & $\begin{array}{l}\text { Fokus infeksi } \\
\text { yang terdeteksi } \\
\text { dengan antibody } \\
\text { monoclonal } \\
\text { ditujukan pada } \\
\text { antigen awal } \\
\text { CMV (sebelum } \\
\text { timbul efek } \\
\text { sitopatik) }\end{array}$ & $\begin{array}{l}\text { Diagnosis } \\
\text { cepat CMV; } \\
\text { kuantifikasi dapat } \\
\text { mengindikasikan } \\
\text { severitas, dapat } \\
\text { digunakan untuk } \\
\text { panduan terapi } \\
\text { preemptif dan durasi, } \\
\text { serta respons terapi }\end{array}$ & $\begin{array}{l}\text { Hasil subjektif; } \\
\text { tidak dapat } \\
\text { digunakan pada } \\
\text { pasien leukopenia }\end{array}$ \\
\hline $\begin{array}{l}\text { Pemeriksaan } \\
\text { antigen }\end{array}$ & $\begin{array}{l}\text { Deteksi pp65 } \\
\text { antigen }\end{array}$ & $\begin{array}{l}\text { Sel } \\
\text { polimorfonuklear }\end{array}$ & 4-6 jam & $\begin{array}{l}\text { Jumlah sel yang } \\
\text { terinfeksi CMV } \\
\text { per total jumlah } \\
\text { sel }\end{array}$ & & \\
\hline
\end{tabular}


Lucyana dkk: Tata laksana infeksi sitomegalovirus pada pasien transplantasi organ padat

\begin{tabular}{|c|c|c|c|c|c|c|}
\hline Metode & Prinsip & Jenis sampel & $\begin{array}{l}\text { Lama } \\
\text { pemeriksaan }\end{array}$ & $\begin{array}{l}\text { Hasil dan } \\
\text { kegunaan klinis }\end{array}$ & Keunggulan & Kekurangan \\
\hline \multicolumn{7}{|c|}{ Metode molekular berbasis asam nukleat } \\
\hline $\begin{array}{l}\text { Nucleic acid } \\
\text { amplification } \\
\text { tests }\end{array}$ & $\begin{array}{l}\text { Amplifikasi } \\
\text { PCR dan } \\
\text { deteksi DNA/ } \\
\text { RNA CMV }\end{array}$ & $\begin{array}{l}\text { Darah, dan } \\
\text { cairan tubuh lain }\end{array}$ & Beberapa jam & $\begin{array}{l}\text { Pemeriksaan } \\
\text { standar } \\
\text { melaporkan } \\
\text { dalam IU/mL; } \\
\text { pemeriksaan } \\
\text { non standar } \\
\text { melaporkan } \\
\text { dalam jumlah } \\
\text { kopi CMV per } \\
\text { volume specimen }\end{array}$ & $\begin{array}{l}\text { Sangat sensitif } \\
\text { dan spesifik untuk } \\
\text { diagnosis CMV, hasil } \\
\text { titer VL membuat } \\
\text { terapi dapat bersifat } \\
\text { individual; menilai } \\
\text { severitas penyakit, } \\
\text { panduan terapi } \\
\text { preemprif, dan } \\
\text { menilai risiko } \\
\text { penyakit, durasi } \\
\text { pengobatan, dan } \\
\text { relaps }\end{array}$ & $\begin{array}{l}\text { Belum ada nilai } \\
\text { ambang yang } \\
\text { disepakati untuk } \\
\text { memprediksi } \\
\text { penyakit CMV; } \\
\text { belum ada } \\
\text { pemeriksaan } \\
\text { standar }\end{array}$ \\
\hline $\begin{array}{l}\text { Nudisens pp67 } \\
\text { test }\end{array}$ & $\begin{array}{l}\text { Deteksi } \\
\text { mRNA }\end{array}$ & $\begin{array}{l}\text { Whole blood, } \\
\text { sampel harus } \\
\text { diproses dalam } \\
24 \text { jam }\end{array}$ & 6 jam & $\begin{array}{l}\text { Pemeriksaan } \\
\text { kualitatif untuk } \\
\text { deteksi infeksi } \\
\text { CMV aktif }\end{array}$ & $\begin{array}{l}\text { Spesifik untuk } \\
\text { replikasi virus; secara } \\
\text { klinis digunakan } \\
\text { untuk terapi } \\
\text { preemptif dan } \\
\text { monitor respon terapi }\end{array}$ & $\begin{array}{l}\text { Pemeriksaan } \\
\text { kualitatif, Lebih } \\
\text { tidak sensitif } \\
\text { dibandingkan } \\
\text { NAT }\end{array}$ \\
\hline $\begin{array}{l}\text { Hybrid capture } \\
\text { assay }\end{array}$ & $\begin{array}{l}\text { Hybrid DNA- } \\
\text { RNA }\end{array}$ & Whole blood & $6 \mathrm{jam}$ & $\begin{array}{l}\text { Jumlah kopi } \\
\text { CMV/mL } \\
\text { (jumlah terendah } \\
\text { deteksi } 7 \times 10^{3} \\
\text { kopi/mL whole } \\
\text { blood) }\end{array}$ & $\begin{array}{l}\text { Sangat spesifik } \\
\text { untuk infeksi CMV; } \\
\text { diagnosis cepat } \\
\text { infeksi CMV }\end{array}$ & $\begin{array}{l}\text { Lebih tidak } \\
\text { sensitif } \\
\text { dibandingkan } \\
\text { NAT }\end{array}$ \\
\hline
\end{tabular}

menggunakan teknologi PCR untuk mendeteksi sejumlah kecil asam nukleat virus. Namun demikian, CMV dapat ditemukan laten di beberapa sel berinti sehingga NAT berisiko mendeteksi dan mengkuantifikasi CMV yang inaktif atau tidak bereplikasi, sehingga diperlukan suatu pemeriksaan untuk membedakan infeksi virus aktif dari laten. Tanpa adanya pemeriksaan tersebut klinisi harus bergantung pada gejala klinis untuk menginterpretasi hasil pemeriksaan NAT apakah hasil tersebut berasal dari infeksi atau latensi. ${ }^{13}$ Jenis spesimen juga perlu diperhatikan dalam menegakkan diagnosis CMV agar dapat menentukan diagnosis dengan akurat (Tabel 2).

Pemeriksaan CMV DNA dapat dijumpai juga pada individu sehat seropositif. ${ }^{17}$ Untuk itu, saat ini telah dikembangkan metode untuk mendeteksi mRNA, selain deteksi DNA CMV. Deteksi mRNA ini bersifat lebih spesifik untuk infeksi CMV aktif karena RNA diproduksi saat replikasi CMV, ${ }^{18,19}$ tetapi sensitivitas lebih rendah dibandingkan DNA.
Sayangnya, molekul RNA didegradasi dengan cepat, dan hal ini secara in vitro dapat menjadi negatif palsu $^{18,19}$ sehingga pengiriman dan penyediaan sampel menjadi sangat penting.

\section{Profilaksis dan terapi preemptif CMV}

Terdapat 2 strategi utama pengobatan penyakit CMV. Pertama adalah profilaksis yang menggunakan antivirus pada semua pasien pasca-transplan yang berisiko menderita penyakit CMV, atau dengan monitoring preemptif pada pasien berisiko untuk mencari infeksi subklinis, dan dengan melakukan pemeriksaan serial PCR CMV atau pp65 antigenemia. Pada kondisi terakhir, antivirus diberikan apabila nilai cut-off $>5000 \mathrm{kopi} / \mathrm{ml}$ telah terlampaui. ${ }^{34}$ Namun, perlu diingat bahwa nilai potong mungkin berbeda untuk beberapa laboratorium.

Gansiklovir intravena dan valgansiklovir oral merupakan antiviral yang paling sering digunakan 
Lucyana dkk: Tata laksana infeksi sitomegalovirus pada pasien transplantasi organ padat

Tabel 2. Beberapa spesimen untuk pemeriksaan $\mathrm{CMV}^{13}$

\begin{tabular}{|c|c|}
\hline Spesimen & Keterangan \\
\hline Darah & $\begin{array}{l}\text { Patogen CMV laten dapat dideteksi pada sampel darah yang mengandung leukosit (whole blood atau } \\
\text { leukosit darah perifer), untuk itu agar pemeriksaan dapat lebih menandakan infeksi akut aktif digunakan } \\
\text { plasma yang tidak mengandung sel }{ }^{20} 983 \text { blood samples, plasma PCR assays with three different primer } \\
\text { sets (UL125 alone, UL126 alone, and UL55/UL123-exon } 4 \text { atau serum. }{ }^{21,22} \text { CMV dari plasma dapat juga } \\
\text { berasal dari sel leukosit lisis atau dari situs terinfeksi seperti parenkim dan sel endotel. }\end{array}$ \\
\hline $\begin{array}{l}\text { Cairan serebro } \\
\text { spinal (CSS) }\end{array}$ & $\begin{array}{l}\text { Diindikasikan untuk pasien yang bergejala ensefalitis, meningitis, poliradikulopati, dll. Jika + maka sugestif } \\
\text { penyakit CMV sistem saraf pusat. }{ }^{23,24} \text { ventriculoencephalitis }\end{array}$ \\
\hline $\begin{array}{l}\text { Cairan akueus dan } \\
\text { vitreus }\end{array}$ & Berguna untuk mengkonfirmasi diagnosis retinitis $\mathrm{CMV}^{25}$ \\
\hline $\begin{array}{l}\text { Urin dan sampel } \\
\text { lain }\end{array}$ & $\begin{array}{l}\text { CMV dapat dideteksi juga di urin dan feses, namun keduanya bukan sampel yang direkomendasikan untuk } \\
\text { diagnosis CMV }{ }^{30} \text { Sekitar } 50 \% \text { resipien transplan mengekskresi CMV di sekret tubuh seperti urin dan feses } \\
\text { pasca-transplantasi, }{ }^{31} \text { cytomegalovirus (CMV sehingga signifikansi klinisnya hanya minimal hingga sedang, } \\
\text { terutama pada pasien seropositif CMV. Pada pasien dewasa, CMV di urin juga ditemukan pada individu } \\
\text { sehat. Kegunaan deteksi CMV DNA pada urin bayi dan anak mengidikasikan infeksi awal (dan latensi) } \\
\text { atau infeksi aktif. Ditemukannya CMV di urin pasien transplan yang seronegatif mengindikasi infeksi. }{ }^{4} \text {. }\end{array}$ \\
\hline Saluran napas & $\begin{array}{l}\text { Deteksi CMV cairan bilasan alveolar (BAL/ broncho alveolar lavage) dapat mengindikasikan pneumonia } \\
\text { CMV. Persemaian CMV di saliva dan sekret respiratori cukup sering dijumpai, dan didapatkannya DNA } \\
\text { CMV tanpa gejala klinis tidak selalu mengindikasikan pneumonia CMVV }{ }^{26,27,28} \text { Namun jika disertai gejala } \\
\text { klinis hal ini dapat bersifat diagnostik dan mengurangi risiko perlunya tindakan diagnostik dengan biopsi. } \\
\text { Sumber lain mengatakan bahwa ditemukannya CMV di BAL representatif untuk menandakan adanya } \\
\text { replikasi virus di paru. } .^{29}\end{array}$ \\
\hline
\end{tabular}

Tabel 3. Perbedaan terapi preemptif dan profilaksis ${ }^{13}$

\begin{tabular}{|c|c|c|}
\hline Parameter & Terapi preemptif & Profilaksis antiviral \\
\hline Strategi & $\begin{array}{l}\text { Monitor reaktivasi CMV menggunakan pemeriksaan } \\
\text { laboratorium yang sensitive (NAT) } \\
\text { Pemeriksaan lab dilakukan sekali seminggu, atau lebih } \\
\text { sering jika pasien dianggap berisiko. } \\
\text { Antiviral (valgansiklovir) hanya diberikan pada pasien } \\
\text { yang mengalami reaktivasi CMV } \\
\text { Monitor menggunakan CMV NAT sekali seminggu } \\
\text { untuk menetukan durasi, dan terapi dilanjutkan sampai } \\
\text { VL tidak terdeteksi atau di bawah ambang batas. }\end{array}$ & $\begin{array}{l}\text { Pemberian antiviral pada jangka waktu tertentu } \\
\text { untuk semua pasien yang berisiko mengalami } \\
\text { penyakit CMV. } \\
\text { Monitoring reaktivasi CMV dengan NAT tidak } \\
\text { direkomendasikan untuk rutin dilakukan }\end{array}$ \\
\hline Populasi target & $\begin{array}{l}\text { Seropositif CMV } \\
\text { Dapat digunakan untuk CMV seronegatif namun lebih } \\
\text { tidak disukai karena dapat terjadi ledakan penyakit } \\
\text { CMV } \\
\text { Tidak direkomendasikan untuk resipien transplan } \\
\text { paru, usus }\end{array}$ & $\begin{array}{l}\text { Semua resipien CMV D+/R-, atau resipien } \mathrm{R}+ \\
\text { transplantasi paru-paru, usus } \\
\text { Semua resipien seropositive transplan jantung, hati, } \\
\text { dan pancreas } \\
\text { Semua pasien transplan yang tidak memiliki akses } \\
\text { untuk deteksi reaktivasi CMV }\end{array}$ \\
\hline Keunggulan & $\begin{array}{l}\text { Mengurangi jumlah pasien yang terpajan antivirus } \\
\text { Mengurangi biaya pemberian antiviral } \\
\text { Mengurangi toksistas yang berkaitan dengan terapi } \\
\text { antivirus } \\
\text { Menurunkan risiko resistensi antivirus }\end{array}$ & $\begin{array}{l}\text { Mencegah reaktivasi herpes virus lain } \\
\text { Tidak bergantung pada pemeriksaan khusus untuk } \\
\text { mendeteksi CMV } \\
\text { Mengurangi insidens timbulnya efek tidak langsung } \\
\text { CMV }\end{array}$ \\
\hline Kekurangan & $\begin{array}{l}\text { Membutuhkan pemeriksaan untuk identifikasi infeksi } \\
\text { CMV } \\
\text { Belum ada nilai ambang batas yang disepakati untuk } \\
\text { inisiasi terapi } \\
\text { Biaya tinggi untuk pemeriksaan yang dikerjakan }\end{array}$ & $\begin{array}{l}\text { Penggunaan jangka panjang dapat meningkatkan } \\
\text { risiko resistensi, terjadinya efek simpang obat } \\
\text { Memerlukan biaya tinggi }\end{array}$ \\
\hline
\end{tabular}


untuk profilaksis dan terapi preemptif. ${ }^{35}$ Secara umum, valgansiklovir sekali sehari memiliki efektivitas setara dengan gansiklovir oral 3 kali per hari untuk profilaksis. ${ }^{6}$ Profilaksis lebih direkomendasikan dan lebih efektif untuk mencegah timbulnya penyakit CMV dibandingkan terapi preemptif pada populasi berisiko seperti resipien transplan hati. ${ }^{36}$ Profilaksis universal diberikan pada donor +/resipien -, selama 3-6 bulan pascatransplan, yaitu valgansiklovir $900 \mathrm{mg} /$ hari (dosis anak: $7 \mathrm{x}$ luas permukaan badan $\mathrm{x}$ klirens kreatinin), atau gansiklovir oral (3 g/hari), atau gansiklovir intravena $(5 \mathrm{mg} / \mathrm{kg} / \mathrm{dosis}$, $2 \mathrm{x} /$ hari $)$.

Strategi kedua adalah pemberian terapi preemptif pada (1) pasien seronegatif CMV dan/atau seropositif yang memiliki titer $>100.000 \mathrm{kopi} / \mathrm{ml}$, (2) pasien yang mendapat bolus steroid atau ATG/ OKT3 untuk rejeksi, berapapun titer DNA virus. Terapi yang diberikan adalah gansiklovir $(5 \mathrm{mg} / \mathrm{kg}$ bid iv), atau valgansiklovir (900 mg bid oral). ${ }^{47,35}$ Valgansiklovir oral diberikan pada resipien transplan hati dengan fungsi cangkok yang stabil. ${ }^{35}$ Terapi preemptif dihentikan apabila didapatkan dua kali berturut-turut hasil PCR DNA CMV negatif selama terapi. Hingga saat ini durasi terapi IV maupun oral belum jelas dan pemeriksaan DNA serial dapat menjadi patokan. Episode rekuren infeksi aktif ditatalaksana menggunakan terapi gansiklovir tambahan jika DNA di atas $100.000 \mathrm{kopi} / \mathrm{mL} .^{3}$ Perbedaan antara terapi preemptif dan profilaksis

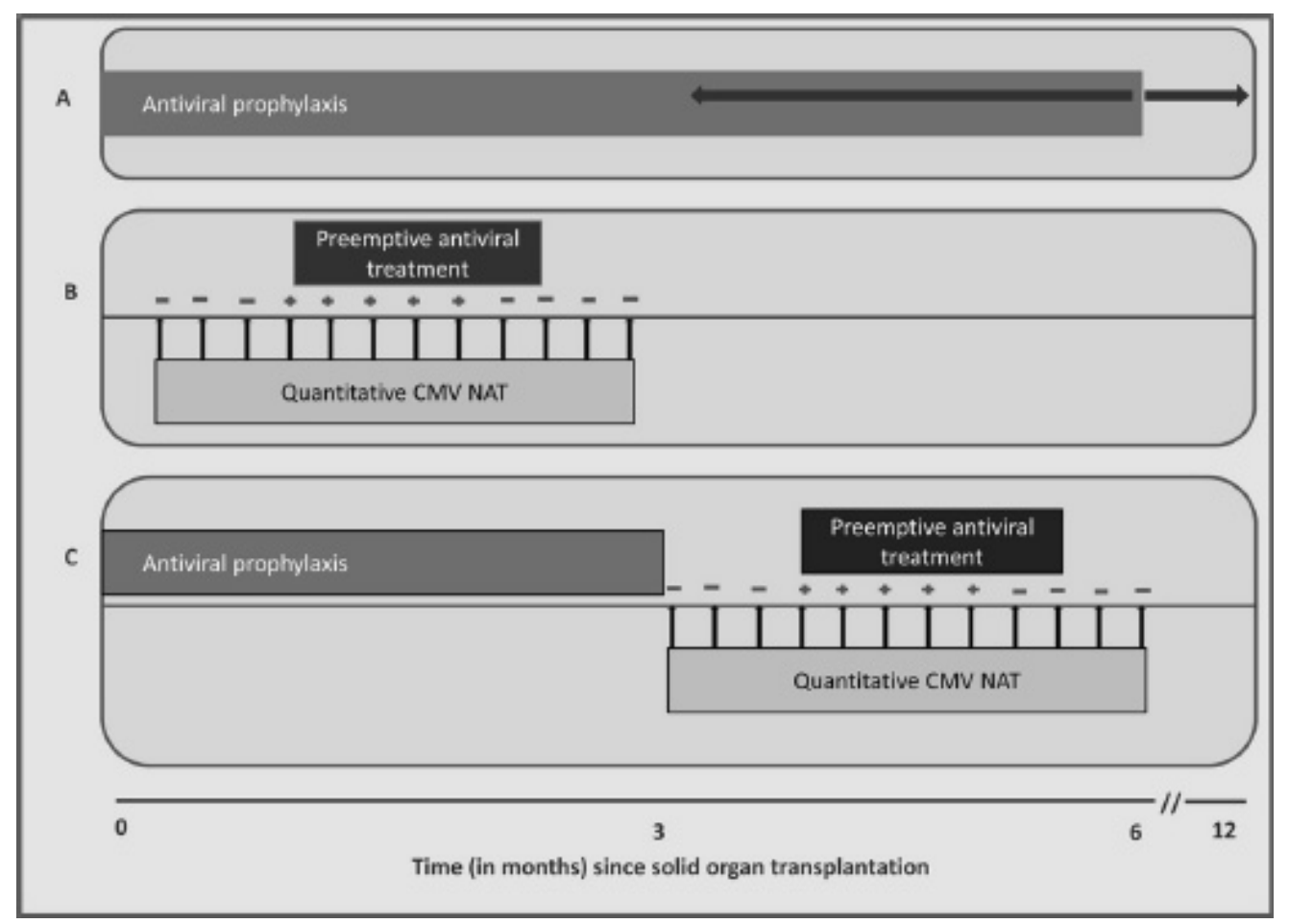

Gambar 2. Bagan pencegahan penyakit CMV pada resipen transplantasi organ padat ${ }^{13}$

Keterangan: A. profilaksis antiviral diberikan antivirus, misalnya valgansiklovir, pada seluruh pasien berisiko selama selang waktu tertentu pasca transplantasi, secara umum diambil 3-6 bulan, namun dapat dipersingkat atau diperpanjang bergantung pada profil risiko. B. Terapi preemptif, didasarkan pada pemeriksaan NAT CMV darah (biasanya mingguan), jika didapatkan titer di atas batas, maka terapi antiviral diinisiasi dan dilanjutkan hingga titer virus di bawah batas yang secara klinis relevan. Pemeriksaan viral load ini biasanya dilakukan pada 3 bulan pertama pasca transplantasi. C. Pendekatan gabungan. Pendekatan ini dilakukan apabila profilaksis antiviral diikuti dengan terapi preemptif, dengan tujuan mengurangi insidens penyakit CMV onset lambat pada pasien transplan risiko tinggi yang diberikan profilaksis antiviral sebagai metode utama pencegahan CMV. 
tertera pada Tabel 3.

Batas viral load yang bersifat spesifik digunakan untuk mendeteksi CMV pada masing-masing pusat transplantasi, yang digunakan untuk menuntun terapi preemptif guna mencegah CMV asimtomatik menjadi penyakit. Suatu pusat transplantasi menyarankan viral load $1000-5000 \mathrm{kopi} / \mathrm{mL}$ plasma sebagai batas optimal untuk menuntun terapi preemptif. Namun, studi prospektif terbaru menguantifikasi viral load menggunakan NAT CMV terstandarisasi dan menyarankan kadar 3,983 IU/ml plasma sebagai batas inisiasi terapi preemptif pada resipien transplan hati, ginjal, dan jantung risiko sedang, seropositif CMV. Kategori risiko resipien transplan berdasarkan serologi adalah risiko tinggi $(\mathrm{D}+/ \mathrm{R}-)$, risiko sedang $(\mathrm{D}+/ \mathrm{R}+$ dan $\mathrm{D}-/ \mathrm{R}+)$, dan risiko rendah (D-/R-). ${ }^{30}$

Sebelum ketersediaan gansiklovir, penyakit CMV yang fatal dapat terjadi pada anak resipien transplan organ padat. ${ }^{6}$ Infeksi simtomatik
CMV dapat mencapai $40 \%$ pasien resipien transplan. ${ }^{2}$ Akhir-akhir ini, penyakit CMV fatal jarang ditemukan. Akan tetapi, viremia masih berhubungan dengan meningkatnya kematian dan retransplantasi pada anak resipien transplantasi paru. ${ }^{37}$

Terapi gansiklovir intravena diberikan bersamaan dengan berkurangnya penggunaan imunosupresan, kecuali jika ada bukti terjadinya rejeksi. Respons klinis akan dijumpai dalam 5-7 hari. Respons klinis timbul lebih awal sebelum klirens viral (15 hari). Monitoring CMV seminggu sekali direkomendasikan untuk menilai respon terapi. Lama terapi didasarkan pada klirens virus CMV yang didapatkan dengan pemeriksaan kuantitatif serial. ${ }^{16,4}$ Terapi antivirus direkomendasikan sampai terjadi eradikasi virus atau sampai batas titer virus yang telah ditentukan aman untuk menghentikan terapi antivirus, yaitu $<137 \mathrm{IU} / \mathrm{mL}\left(2.14 \log _{10}\right){ }^{8,33}$ Walaupun terdapat

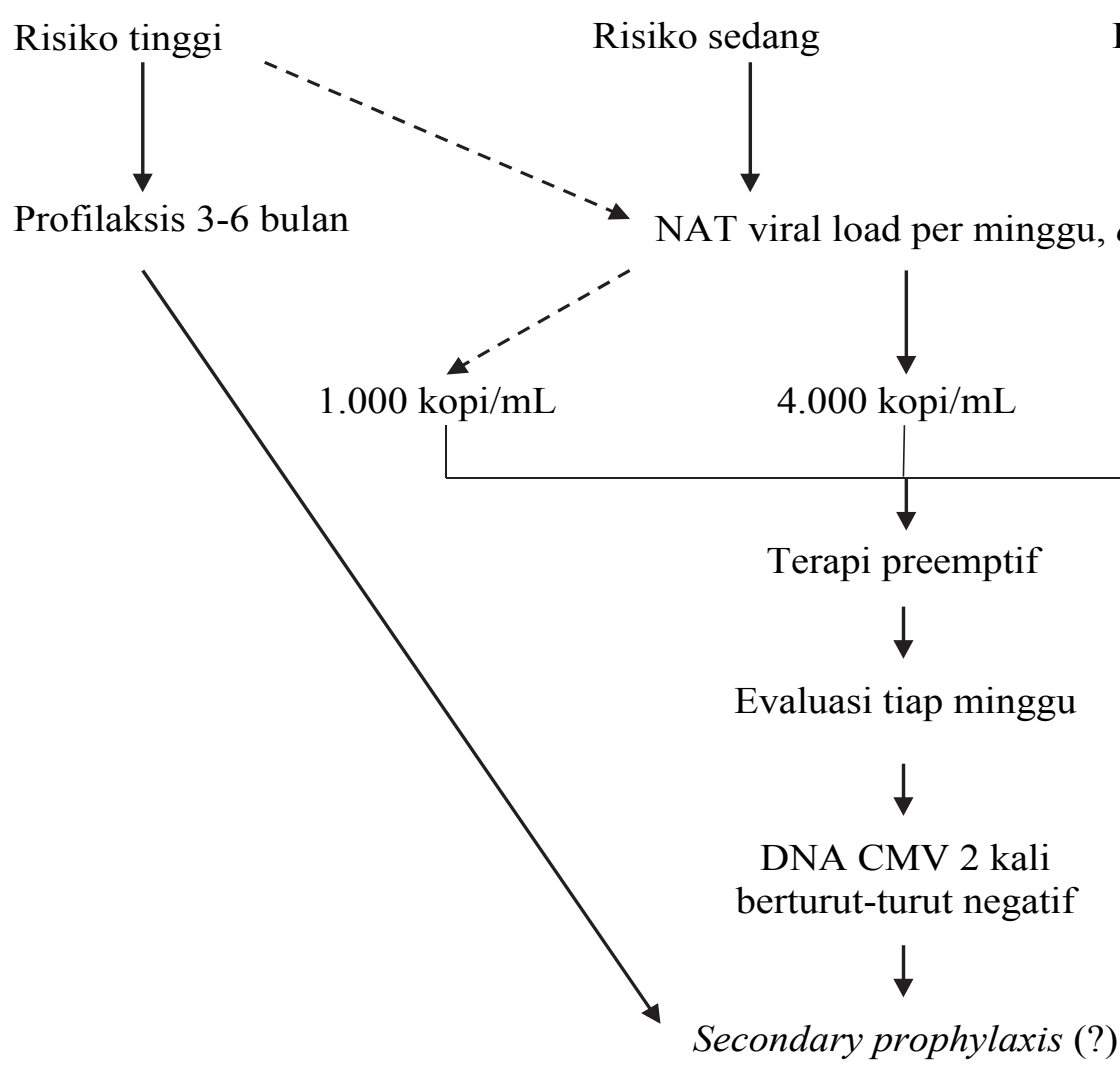

Gambar 3. Tata laksana penyakit CMV dan pencegahan pada pasien transplan organ padat ${ }^{13}$ 
Lucyana dkk: Tata laksana infeksi sitomegalovirus pada pasien transplantasi organ padat

risiko terjadi neutropenia pada terapi preemptif CMV, insidens infeksi tidak meningkat. Lama terapi preemptif dapat disesuaikan pada pasien transplantasi hati yang memiliki risiko lebih tinggi mengalami neutropenia. ${ }^{38}$

Selain efek langsung infeksi CMV, terdapat efek tidak langsung berupa meningkatnya risiko infeksi lain, angka rejeksi, dan kematian. Efek tidak langsung infeksi CMV, misalnya, infeksi CMV pada pasien transplan hati dapat meningkatkan risiko infeksi hepatitis $\mathrm{C}$ dan penyakit limfoproliferatif pasca-transplan. Efek tidak langsung tersebut dapat disebabkan beberapa proses patologis, termasuk imunomodulasi dan imunosupresi, timbulnya respons proinflamasi, sitotoksik, dan proliferasi otot polos. Profilaksis menggunakan antivirus dapat mengurangi risiko terjadinya penyakit CMV sehingga meningkatkan luaran baik secara keseluruhan. Profilaksis antivirus harus dipertimbangkan pada semua pasien yang berisiko mengalami infeksi CMV pasca-transplan. ${ }^{7}$ Gambar 2 menampilkan sekuens waktu pada terapi profilaksis dan terapi preemptif.

Gambar 3 menunjukkan algoritme pendekatan yang dapat dilakukan pada pencegahan CMV. Dua jenis pendekatan dapat dikerjakan untuk kelompok risiko tinggi, yaitu profilaksis atau preemptif. Namun, titer cut-off yang direkomendasikan untuk beberapa tingkat risiko dikatakan berbeda dari beberapa kepustakaan. Semakin berisiko maka batas titer CMV darah yang mengindikasikan terapi akan semakin rendah. Evaluasi dilakukan mingguan selama pengobatan CMV untuk melihat titer CMV darah. Pengobatan dihentikan apabila telah didapatkan 2 kali titer negatif, atau di bawah batas yang dianggap secara klinis bermakna. Namun demikian, seperti yang telah disebutkan di atas, bahwa hingga saat ini nilai ambang batas yang disepakati belum ada karena standar pengukuran yang digunakan untuk pemeriksaan CMV DNA bervariasi sehingga nilai ini sifatnya spesifik berdasarkan pusat transplantasi masing-masing dan harus disesuaikan kembali dengan klinis pasien. Profilaksis sekunder setelah pasien diberikan terapi preemptif saat ini masih belum dibakukan.

\section{Daftar pustaka}

1. Green M, Michaels MG. Infections in pediatric solid organ transplant recipients. J Pediatr Infect Dis Soc 2012;1:144-51.

2. Halasa N, Green M. Immunizations and infectious diseases in pediatric liver transplantation. Liver Transpl 2008;14:1389-99.

3. Fagiuoli S, Colli A, Bruno R, dkk. Management of infections pre- and post-liver transplantation: Report of an AISF consensus conference. J Hepatol 2014;60:1075-89.

4. Ramanan P, Razonable RR. Cytomegalovirus infections in solid organ transplantation: A review. Infect Chemother 2013;45:260-71.

5. Breinig MK, Zitelli B, Starzl TE, Ho M. Epstein-Barr virus, cytomegalovirus, and other viral infections in children after liver transplantation. J Infect Dis 1987;156:273-9.

6. Fishman JA. Infection in solid-organ transplant recipients. N Engl J Med 2007;357:2601-14.

7. Roman A, Manito N, Campistol JM, dkk. The impact of the prevention strategies on the indirect effects of CMV infection in solid organ transplant recipients. Transplant Rev Orlando Fla 2014;28:84-91.

8. Emery VC, Cope AV, Bowen EF, Gor D, Griffiths PD. The dynamics of human cytomegalovirus replication in vivo. J Exp Med 1999;190:177-82.

9. Eid AJ, Brown RA, Arthurs SK, Lahr BD, Eckel-Passow JE, Larson TS, Razonable RR. A prospective longitudinal analysis of cytomegalovirus (CMV)-specific CD4+ and CD8+ T cells in kidney allograft recipients at risk of CMV infection. Transpl Int 2010;23:506-13.

10. Paya C, Humar A, Dominguez E, dkk. Efficacy and safety of valganciclovir vs. oral ganciclovir for prevention of cytomegalovirus disease in solid organ transplant recipients. Am J Transplant 2004;4:611-20.

11. Stowell JD, Forlin-Passoni D, Din E, dkk. Cytomegalovirus survival on common environmental surfaces: opportunities for viral transmission. J Infect Dis 2012;205:211-4.

12. Watkins RR, Lemonovich TL, Razonable RR. Immune response to CMV in solid organ transplant recipients: current concepts and future directions. Expert Rev Clin Immunol 2012;8:383-93.

13. Razonable RR, Hayden RT. Clinical utility of viral load in management of cytomegalovirus infection after solid organ transplantation. Clin Microbiol Rev 2013;26:703-27.

14. Grefte A, van der Giessen M, van Son W, The TH. Circulating cytomegalovirus (CMV)-infected endothelial cells in patients with an active CMV infection. J Infect Dis 1993;167:270-7.

15. Dunn HS, Haney DJ, Ghanekar SA, Stepick-Biek P, Lewis DB, Maecker HT. Dynamics of CD4 and CD8 T cell responses to cytomegalovirus in healthy human donors. J Infect Dis 2002;186:15-22. 
Lucyana dkk: Tata laksana infeksi sitomegalovirus pada pasien transplantasi organ padat

16. Humar A, Snydman D, AST Infectious diseases community of practice. Cytomegalovirus in solid organ transplant recipients. Am J Transplant 2009;9 Suppl 4:S78-86.

17. Larsson S, Söderberg-Nauclér C, Wang FZ, Möller E. Cytomegalovirus DNA can be detected in peripheral blood mononuclear cells from all seropositive and most seronegative healthy blood donors over time. Transfusion 1998;38:271-8.

18. Gozlan J, Salord JM, Chouaïd C, Duvivier C, Picard O, Meyohas MC, Petit JC. Human cytomegalovirus (HCMV) late-mRNA detection in peripheral blood of AIDS patients: diagnostic value for HCMV disease compared with those of viral culture and HCMV DNA detection. J Clin Microbiol 1993;31:1943-5.

19. Randhawa PS, Manez R, Frye B, Ehrlich GD. Circulating immediate-early mRNA in patients with cytomegalovirus infections after solid organ transplantation. J Infect Dis 1994;170:1264-7.

20. Boeckh M, Huang M, Ferrenberg J, Stevens-Ayers T, Stensland L, Nichols WG, Corey L. Optimization of quantitative detection of cytomegalovirus DNA in plasma by real-time PCR. J Clin Microbiol 2004;42:1142-8.

21. Eckart P, Brouard J, Vabret A, Freymuth F, Guillot M, Ryckelynck JP, Hurault de Ligny. Detection of human cytomegalovirus in renal transplantation: comparison of four diagnostic methods: DNA in sera by polymerase chain reaction (PCR), DNA in leukocyte by PCR, pp65 leukocytic antigenemia, and viremia. Transplant Proc 1997;29:2387-9.

22. Cunningham R, Harris A, Frankton A, Irving W. Detection of cytomegalovirus using PCR in serum from renal transplant recipients. J Clin Pathol 1995;48:575-7.

23. Arribas JR, Clifford DB, Fichtenbaum CJ, Commins DL, Powderly WG, Storch GA. Level of cytomegalovirus (CMV) DNA in cerebrospinal fluid of subjects with AIDS and CMV infection of the central nervous system. J Infect Dis 1995;172:527-31.

24. Revello MG, Percivalle E, Sarasini A, Baldanti F, Furione M, Gerna G. Diagnosis of human cytomegalovirus infection of the nervous system by pp65 detection in polymorphonuclear leukocytes of cerebrospinal fluid from AIDS patients. J Infect Dis 1994;170:1275-9.

25. Harper TW, Miller D, Schiffman JC, Davis JL. Polymerase chain reaction analysis of aqueous and vitreous specimens in the diagnosis of posterior segment infectious uveitis. Am J Ophthalmol 2009;147:140-7.e2.

26. Chemaly RF, Yen-Lieberman B, Chapman J, dkk. Clinical utility of cytomegalovirus viral load in bronchoalveolar lavage in lung transplant recipients. Am J Transplant 2005;5:544-8.

27. Stéphan F, Fajac A, Grenet D, dkk. Predictive value of cytomegalovirus DNA detection by polymerase chain reaction in blood and bronchoalveolar lavage in lung transplant patients. Transplantation 1997;63:1430-5.

28. Chemaly RF, Yen-Lieberman B, Castilla EA, dkk. Correlation between viral loads of cytomegalovirus in blood and bronchoalveolar lavage specimens from lung transplant recipients determined by histology and immunohistochemistry. J Clin Microbiol 2004;42:2168-72.

29. Kerschner H, Jaksch P, Zweytick B, Puchhammer-Stöckl E. Detection of human cytomegalovirus in bronchoalveolar lavage fluid of lung transplant recipients reflects local virus replication and not contamination from the throat. J Clin Microbiol 2010;48:4273-4.

30. Razonable RR, Humar A, AST Infectious Diseases Community of Practice. Cytomegalovirus in solid organ transplantation. Am J Transplant Off J Am Soc Transplant Am Soc Transpl Surg 2013;13 Suppl 4:93-106.

31. Sia IG, Patel R. New strategies for prevention and therapy of cytomegalovirus infection and disease in solid-organ transplant recipients. Clin Microbiol Rev 2000;13:83-121.

32. Piiparinen H, Höckerstedt K, Grönhagen-Riska C, Lautenschlager I. Comparison of two quantitative CMV PCR tests, Cobas Amplicor CMV Monitor and TaqMan assay, and pp65-antigenemia assay in the determination of viral loads from peripheral blood of organ transplant patients. J Clin Virol 2004;30:258-66.

33. Razonable RR, Åsberg A, Rollag H, Duncan J, Boisvert D, Yao JD, dkk. Virologic suppression measured by a cytomegalovirus (CMV) DNA test calibrated to the World Health Organization international standard is predictive of CMV disease resolution in transplant recipients. Clin Infect Dis 2013;56:1546-53.

34. Green M, Marian M. Preemptive therapy of cytomegalovirus disease in pediatric transplant recipients. Pediatr Infect Dis J 2000;19:875-7.

35. Kim JM, Kwon CHD, Joh J-W, dkk. Oral valganciclovir as a preemptive treatment for cytomegalovirus (CMV) Infection in CMV-seropositive liver transplant recipients. PLOS ONE 2015;10:e0123554.

36. Bodro M, Sabé N, Lladó L, dkk. Prophylaxis versus preemptive therapy for cytomegalovirus disease in high-risk liver transplant recipients. Liver Transpl 2012;18:1093-9.

37. Danziger-Isakov LA, Worley S, Michaels MG, dkk. The risk, prevention, and outcome of cytomegalovirus after pediatric lung transplantation. Transplantation 2009;87:1541-8.

38. Martín-Gandul C, Pérez-Romero P, González-Roncero FM, dkk. Clinical impact of neutropenia related with the preemptive therapy of CMV infection in solid organ transplant recipients. J Infect 2014;69:500-6.

39. Allen U, Hebert D, Petric M, dkk. Utility of semiquantitative 
Lucyana dkk: Tata laksana infeksi sitomegalovirus pada pasien transplantasi organ padat

polymerase chain reaction for Epstein-Barr virus to measure virus load in pediatric organ transplant recipients with and without posttransplant lymphoproliferative disease. Clin Infect Dis 2001;33:145-50. 